Part Three

Material Culture 


\section{Excess, Distortion, and Archival Value Exhibiting the East German Everyday at the Wende Museum}

\section{Sara Blaylock}

This paper argues for the significance of East Germany's Alltagsgeschichte (everyday history) as both a source of information about the past and as a means to nuance popular conceptions of the Cold War-era's communist Germany. Its focus on the Wende Museum, a private nonprofit archive and museum of Cold War culture located in Culver City, California, addresses the bridge that such an institution can make between popular and scholarly understandings of the Cold War. Considering the significance that location has had on the narrating of the East German past, as well as the impact of new ways of historicizing objects that embrace ambiguity and uncertainty, this paper uses the Wende Museum as an allegory for the benefits that open-ended collections can offer into how history is made and remade.

Keywords: East Germany, German Democratic Republic, Cold War, everyday history, Alltagsgeschichte, material culture, memory, archive, museums, Wende.

In order to conjure the look of East Germany, director Florian Henckel von Donnersmarck filtered The Lives of Others's (2006) color to a dull hum ("The Lives of Others Sound, Set and Colour"). Even today, a visit to Berlin's Alexanderplatz characterizes the socialist country's yen for concrete. Such images confirm the East Germany in mind, which is to say, the anticipated subject, but inadequately 
represent its lived experience. Certainly, the image of the German Democratic Republic (GDR) as an austere and foreboding space gives a portion of its public face. Nevertheless, after seeing The Lives of Others, an East German remarked: "Everything that was portrayed in the film happened. But it didn't happen LIKE THAT. 1000 details were off" (Boyer, "From Algos to Autonomos" 24). This reaction is typical and represents the challenge current scholars of East Germany face. The history of this country has largely been written from the perspective of the state via Stasi and other government documents (Kelly and Wlordarski 10). Indeed, the central criticism that scholars levy against The Lives of Others has been its humanization of the Stasi-specifically the way its central figure, a Stasi operative, receives an "aesthetic education" that inspires him to protect the author under his observation and leads ultimately to a humiliating demotion (Dueck 606). That critique runs counter to the many awards the film has received, including an Oscar for Best Foreign Language Film in 2006, and also demonstrates the significant rift between popular notions of life in the GDR and the critical assessments offered by many historians, art historians, and museum professionals. What remains off or skewed by the record are the less dramatic experiences of the everyday (Alltag). Importantly, a shift among leading historians of the GDR, including Mary Fulbrook and Konrad Jarausch, has modeled a move away from theories of totalitarianism or dictatorship towards social or people's histories. ${ }^{1}$ This paper argues for the significance of the Alltag as both a

${ }^{1}$ For a discussion of this shift, see Andrew I. Port. "The Banalities of East German Historiography." Becoming East German. Socialist Structures and Sensibilities after Hitler. Eds. Mary Fulbrook and Andrew I. Port (New York \& Oxford: Berghahn Books, 2013), 16-24. Print. 
source of information about the past and as a site of resistance against a master narrative that has narrowed popular understandings of East German experience. Its focus on the Wende Museum, a private non-profit archive and museum of Cold War culture located in Culver City, California, addresses the bridge that such an institution can make between popular and scholarly understandings of the Cold War. Considering the significance that location has had on the narrating of the East German past and employing the theory of Pierre Nora, I seek to demonstrate how as a receptacle of memory objects, that is to say a living archive as well as a museum, the Wende Museum may be understood as a lieux de mémoire (site of memory) with a critical (read: geographic) distance from the actual placewhat Nora call's mileux de mémoire (environment of memory) — of East German history. This article, in keeping with Susan Crane's research on museums as contested sites of memory, argues that the Wende Museum's unique California location and collecting vision permits it to embrace "excess" and "distortion" that define personal memory to its advantage (Crane 46 and 57). In the words of Gabriella Giannachi, "To look at archives as material archaeological sites allows us to capture not only the plots and timelines that link pasts to presents and possible futures, but also to understand how societies deal with what is as yet absent from the complex ways in which they construct their presence in history" (Giannachi 33). In sum, my focus is on defining - by way of treating this Cold War museum/archive as allegory for new ways of historicizing through objects - the benefits, or at least the insights, that collections can offer into how history is made and remade. 


\section{The Stakes}

Formally established in 2002, the Wende Museum has a collection of over 100,000 artifacts. Its East German collection, which accounts for nearly $75 \%$ of holdings, is the largest of its kind outside of Germany (Biehl). The Wende Museum preserves GDR culture in material memory and actively resists the tendency in German-not to mention American ${ }^{2}$-Cold War museums and histories to interpret East German reality through a purely political lens. It also maintains a collecting vision that focuses on East Germany's relationships to former Eastern Bloc countries and Soviet Russia, a quality that distinguishes it from museums of the GDR located in Germany. Importantly, breadth of interpretation (what Crane might refer to as a form of "excess" or "distortion") has also enabled a more expansive programming agenda. Historians and in particular museum professionals working in Germany have tended to resist this alternative model of historicization. For example, Rainer Eckert who directs the Zeitgeschichtliches Forum (ZGF, Contemporary History Museum) in Leipzig, part of the national Haus der Geschichte der Bundesrepublik Deutschland (House of the History of the Federal Republic of Germany, $\mathrm{HoH}$ ), does not "understand the point of what [the Wende Museum] is doing," and maintains that "almost everything is already documented in Germany...I don't really see what this could add to the debate. In many ways, the GDR is better documented than any other period in German history" (cited in Biehl).

\footnotetext{
${ }^{2}$ For more on the subject of ambiguous Cold War museification in the USA, see Jon Wiener. How We Forgot the Cold War: A Historical Journey Across America. Berkeley: University of California Press, 2012. Print.
} 
However, Wende Museum director and founder Justinian Jampol argues that "if the items in [this] collection were deemed of historical or aesthetic value, they would be housed in the appropriate institutions, and the museum would not exist" (Jampol, "GDR on the Pacific" 258). His perspective resounds both in the museum collections and their origins. East Germans have recognized the significance of the Wende Museum project since its inception, evident in the surfeit of highly personal donations they have made to its collection. The museum is correcting, or better said compensating for, a multifaceted disposal of artifacts from the GDR. In 1990, the East Germans reportedly disposed of 19 million tons, at a rate of 1.2 tons per individual - three times the rate per capita of West Germans in the same period (Jampol, "Beyond the Wall" 11). (Scenes from the massive trash heaps outside of the Plattenbau in the 2003 film Good Bye, Lenin! [dir. Wolfgang Becker] illustrate this phenomenon well.)

Home renovations were no doubt propelled by an increased access to Western goods, which had actually always been somewhat within reach through the black market or state-run "Intershops." Likewise the financial boon of the promised 100DM Begrïßungsgeld (welcome money) offered to East Germans who entered the Federal Republic made consumer spending a greater possibility in the weeks and months after the collapse of the Berlin Wall. As Time Magazine reports, "no official statistics exist as to exactly how much was claimed in all, but by the time payments were halted on December 29, 1989, replaced by a foreign currency fund that both German states contributed to, it's estimated that at least four billion DM had been paid out in a matter of just seven weeks" (Jack). Free money and the excitement of new home décor cannot explain, of course, the rapid removal of East German culture from a 
unified Germany. Street names were changed, buildings and monuments torn down, ${ }^{3}$ and large collections of East German artifacts and art were deaccessioned or stored in largely inaccessible depots. Jampol joins other historians and museum professionals in the belief that "this movement was part of a wide and often silent process of excluding East Germany, and those who had lived in it, from belonging to the history of the "new' Germany" (Jampol, "Beyond the Wall" 11-12). Here, it is in fact of some import that Jampol began collecting East German artifacts while researching the evolution of the GDR's political iconography for both his master's thesis and doctoral dissertation (Bach, Cuevas-Wolf and Kranz 131-132). His hunt for objects-few of which had been formally catalogued in national museums or archivesdemonstrated to him the gravity of their potential loss for future scholarly inquiry.

${ }^{3}$ Here, the French artist Sophie Calle's 1996 Detachment photo essay offers a non-scientific, but nevertheless immediate, ethnographic sample of the effects-both psychological and physical-of these removals. 


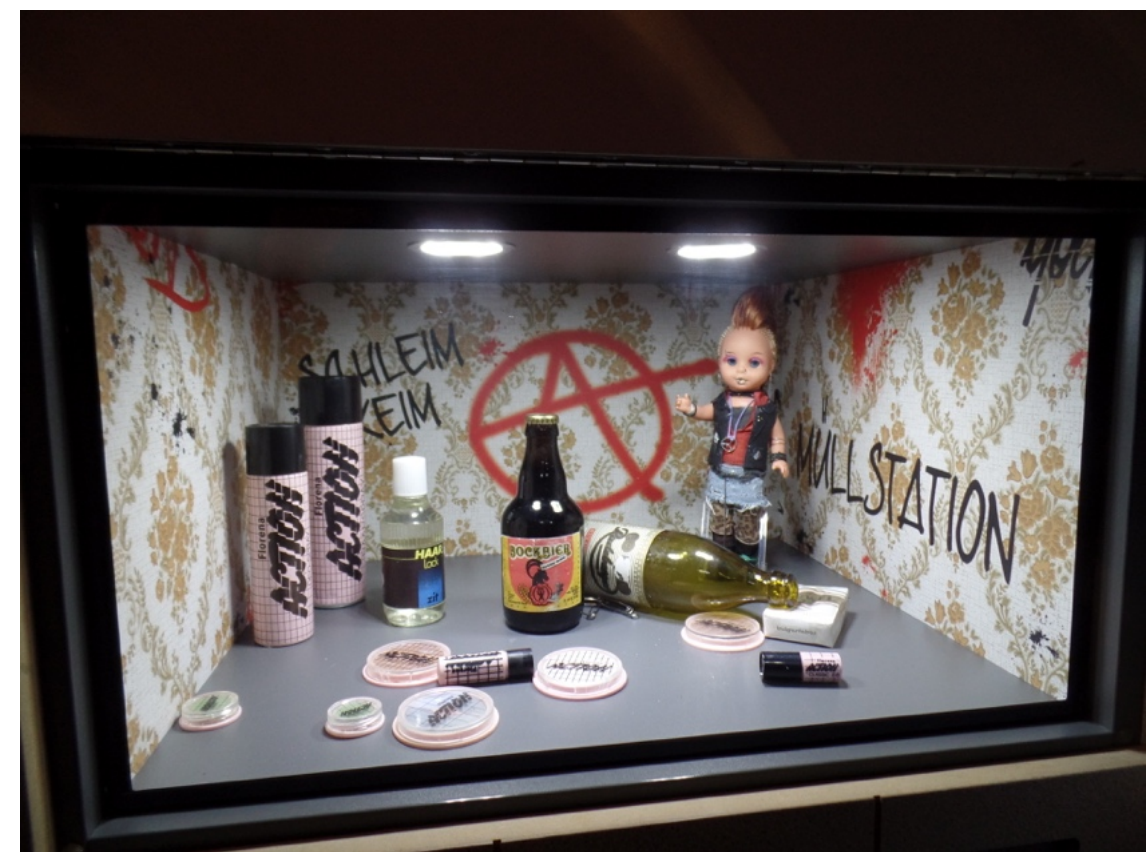

The punk scene on display at the DDR Museum in 2015. A corresponding didactic includes a photograph of punks in the city of Halle and a text that reads: "CHAOS WITHOUT THEORY Playing in cellars and back yards, the punk bands were known for their wild music and even wilder appearancewith colored hair and a ring through their ears and noses. The big 'A' painted on the backs of their jackets stood for 'anarchy.' Interested only in being left alone, the punks did not want to change society or challenge Socialism, but be allowed to live as they pleased. The state responded with harassment and prison sentences." Photo Credit: Sara Blaylock, 2015. 
Although museums of everyday life in the GDR are growing, there has historically been no place for the country's objects of culture to go. The recently opened Museum in der Kulturbrauerei, which features a permanent exhibition entitled Alltag in der DDR (Everyday Life in the GDR), offers a fresh and more thoughtful review of this history than has otherwise been seen in the capital city. A free museum, organized by the House of History (of which the aforementioned ZGF is also a member), the Prenzlauer Berg venue contrasts starkly with the city center's for-profit DDR Museum, which relies on simplified vignettes of East German everyday life. The museum's exhibits-while fastidiously staged and compellingly interactive-inspire more spectating and play than critical engagement from their audience. In fact, a 2008 critique by historian Martin Sabrow raised serious issues with the museum's collecting practices-found to be unsystematic and incomplete-, as well as its storage and display-found to be potentially hazardous to the safety of the objects, both in the archive and on exhibition (Bach, Cuevas-Wolf and Kranz 124). A photograph I took in 2015 at the DDR Museum of its display on punk demonstrates that reductive histories continued well after Sabrow's damaging assessment. ${ }^{4}$ [Figure 1] The Kulturbrauerei museum is an improvement, but nevertheless represents a portion of a collection of "suitable objects that would physically document contemporary history," and encompasses items from East, West, and a reunited Germany (Museum in der Kulturbrauerei). The

4 For more on punk, see Seth Howes. " 'Killersatellit' and Randerscheinung: Punk and the Prenzlauer Berg." German Studies Review 36:3 (October 2013): 579-60. Print. and Seth Howes. "Pessimism and the Politics of the Future in East German Punk." The Journal of Popular Culture 49:1 (February 2016): 77-96. Print. 
general mandate of the museum to record all of modern German history renders its commitments to the GDR tentative. It also isolates East German history within a West/East (specifically German) paradigm that does not fully account for the country's participation in the world of the communist East. The Wende Museum is unique both in its commitments to East Germany, and its overall collecting focus on Cold War-era Eastern Europe and the Soviet Union. This geographic range, in particular, draws to the fore both anticipated and surprising overlaps in communist culture, as well as the more unexpected divergences. Importantly, both the exhibitions, and the archive-which is quite accessible to researchers and for which museum staff offer tours-draw attention to the specificity of state socialist culture in relation to itself, rather than in comparison to capitalism.

In addition to the objects culled from the scouting efforts of its team, the many donations that the Wende Museum receives from historical witnesses-that is to say, East Germans themselves-demonstrate the necessity of this site as an alterative to archives and museums based in Germany. The interest in decluttering an attic, while also seeing the objects of one's personal history as valuable to collective history, is in fact typical of modern memory practices. As Pierre Nora writes, "The quest for memory is the search for one's history" (Nora, "Between Memory and History" 13). Objects in particular define for Nora the essence of modern memory, which he describes as "above all, archival. It relies on the materiality of the trace, the immediacy of the recording, the visibility of the image" (13). The stakes are somewhat higher in Germany. Susan Crane describes the "discourse on memory [as] particularly fraught" in this country, where reunification essentially erased not only the objecthood of the GDR, but also the very 
necessity or relevance of discussing that past (Crane 54). She writes, "The slogan of 1990, 'bringing together what belongs together,' belies the vast differences of experience and memory which people of the same generations bring to the new state from east and west" (54).

Scholars have consistently criticized the manner in which East Germany has been historicized, specifically the ways in which macro-histories have supplanted the necessity for consideration for individual experience (i.e., Alltagsgeschichte, history of everyday life). Anthropologist Daphne Berdahl, for example, has criticized the ZGF for its emphasis on repression and resistance, which ignores the apolitical reality of the Alltag (Berdahl, "Re-Presenting the Socialist Modern" 350). Because it is the country's most important-and visible-federally organized and funded GDR museum in Germany, the ZGF's policies and practices represent the significant national barriers that prevent a more nuanced understanding of Germany's Cold War past (352). Importantly, the ZGF has not altered its vision in spite of the so-called Sabrow Commission of 2004, which found the politically neutral Alltagsgeschichte expressly lacking from Germany's official guidelines on the historicization and exhibition of GDR history. Moreover, ZGF director Eckert's claim that the GDR has already been sufficiently documented underscores the necessity of projects like the Wende Museum, which move beyond the state-created documents to which Eckert refers. In any case, to write a history from these documents is in itself a dubious goal. Cultural historians Katherine Pence and Paul Betts allow that although the state used "tools of the modern bureaucracy and police apparatus...[to monitor] the East German population and [log] records of their participation and protests in vast archives" prolifically and without precedence, these official "histories of the GDR have not 
done much to produce reconciliation and narrative consensus" (Pence and Betts 3). One East German, whose husband informed on her to the Stasi for over a decade, offers an even more vitriolic assessment: "If a future generation of impartial researchers were to reconstruct the face of [East German] society using these [Stasi] files, they would produce only a grotesque grimace, bearing no resemblance to a human countenance" (cited in McLellan 19). Clearly, relying solely on state documents narrates an incomplete and skewed past. ${ }^{5}$ Importantly, the Wende Museum intends to set its collections of Alltag objects and documents in conversation with its holdings of political artifacts to the effect of adding unanticipated detail to familiar histories. The dialogue between "neutral" and more (obviously) loaded artifacts works to "preserve Cold War art, culture, and history from the Soviet Bloc countries, inspire a broad understanding of the period, and explore its enduring legacy" (Wende Museum, "About Us") and aids the understanding of how people experienced "real existing socialism" both within and beyond the party line. This is not to say that the museum avoids discussing the fraught political context of the GDR, especially its surveillance culture. To the contrary, donations by border guards and Stasi employees have led to exhibitions and programs that engage the experiences of the perpetrators in conversation with other historical witnesses. Jampol notes that these donations arrive at the museum from "historical

${ }^{5}$ My research on experimental art from East Germany also engages with state documents, including surveillance records and those of official culture, in a critical way. I have found it essential to combine these more skewed documents with oral histories and independentlyproduced texts as a means of more completely engaging with the history. Sara Blaylock. Infiltration and Excess: Experimental Art as Public Life in the Late East Germany (Manuscript in Progress). 
participants who believe their personal collections would be politicized by European institutions" (Jampol, "Beyond the Wall" 13). Here it is interesting that less controversial donors are motivated by a similar impulse. "Is it Ostaglie ${ }^{6}$ to long for the scents of childhood?," asks one GDR museum located in the former East German state of MecklenburgVorpommern (DDR-Museum Tutow). It is indeed significant that the Wende Museum, located in a city that has long hosted German immigrants, offers a platform for this kind of Proustian encounter.

\section{The Museum itself}

For more than a decade, the museum ${ }^{7}$ was housed in an office park in Culver City-a location, which concealed its unusual contents. Foot traffic and general awareness have increased since the Wende Museum relocated in 2017 to a former armory about 1.5 miles southwest of downtown Culver City. Though most of its collection remains in the archive vault, museum staff organize on-site exhibitions and also lend objects to local and international institutions. Access to materials online, including artifacts and exhibition catalogs, has expanded in recent years. Public programming has also grown prolifically with partnerships being forged with area museums and local artists of particular note. The museum has worked to draw comparisons between Cold War history and the Los Angeles present-with analogies between the Berlin Wall and the US-Mexico border given a particular focus. In addition, programs underscore the important role that

\footnotetext{
${ }^{6}$ A neologism that describes nostalgia for the East (Ost).

${ }^{7}$ The Wende Museum was first established as a foundation in 2002. It moved into its first Culver City location in 2004.
} 
southern California played in the Cold War, specifically with regard to its arms production and sales, which helped to fortify the US against its communist adversaries in the Soviet Union and the Eastern Bloc. In short, LA's own Cold War history, not to mention its large immigrant communities from former Eastern Bloc countries and Soviet Russia, represent not only an underlying but essential connection between the museum's contents and its context. Certainly, the museum's new location in a former armory offers a fitting reminder of these entangled Cold War histories.

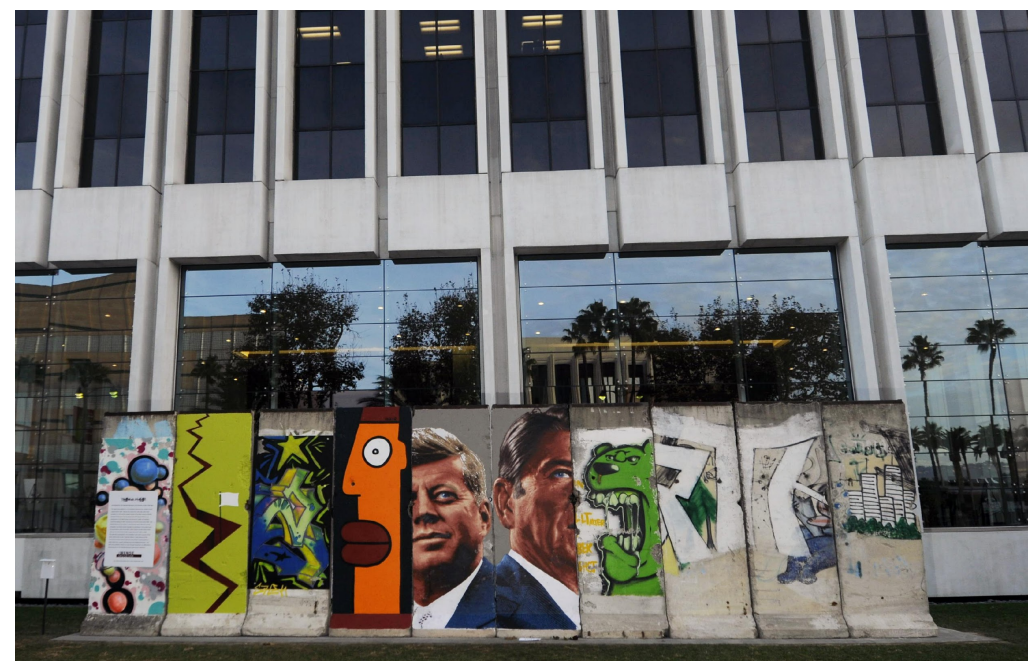

Installation view, Original Berlin Wall Segments at 5900 Wilshire Boulevard,

Los Angeles, California.

Photo Credit: Marie Astrid González, The Wende Museum of the Cold War. 
The Wende Museum's largest public project thus far commemorated the twenty-year anniversary of the fall of the wall in 2009 (Wende Museum, "The Wall Project"). [Figure 2] "The Wall Project" included a temporary roadblock on Wilshire Boulevard and the installation of ten original wall segments across from the Los Angeles County Museum of Art (LACMA). The Wende Museum commissioned four artists to paint five of these segments for permanent display, including Thierry Noir-one of the first graffiti artists to paint the Berlin Wall in 1984-and L.A. muralist, Kent Twitchell. This ambitious and dynamic public sculpture remains installed on Wilshire Boulevard, an ambiguous monument that refers to both Germany's walled in past and contemporary parallels, not least of which the US-Mexico border some 150 miles away. "The Wall Project" deliberately coincided with the opening of the LACMA's new location on Wilshire, a concurrence that epitomizes the Wende Museum's goal to engage with a wider public. In important ways, this project continues the work of the East Side Gallery-a $1.3 \mathrm{~km}$ stretch of Berlin Wall painted in 1990 by 118 artists (including Thierry Noir) from 21 countries as a monument to Germany's reunification. Given the recent removal of portions of the wall to make room for luxury housing along Berlin's Spree River ("Developer Resumes Removal"), the significance of the LA installations has grown increasingly complex and important. Outrage after a 2013 demolition led subsequently to the absorption of the East Side Gallery into the Berlin Wall Foundation, which also conserves and protects the largest portion of intact wall space still in existence, including a small segment of the no-man's-land that divided the East and West German sides of the wall (Daley). As the Berlin Wall's original sites continue to disappear, preservation efforts abroad will continue to raise 
questions as to the significance of these spaces in a postCold War Germany.

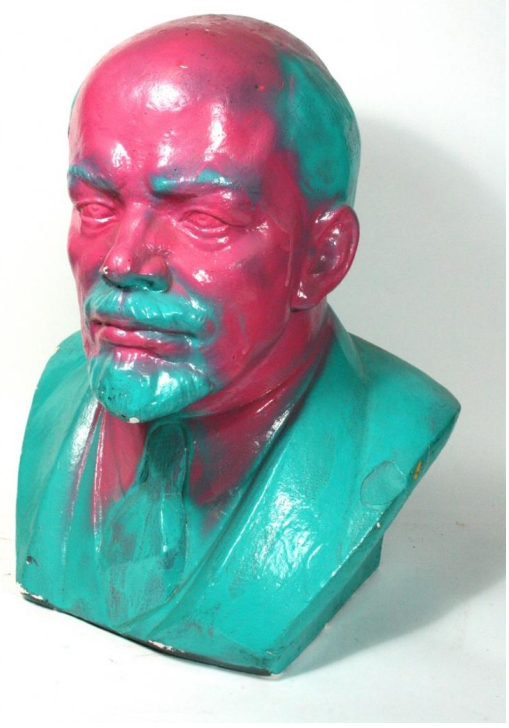

Vandalized Lenin Bust, 1965/1989, East Germany, plaster, $20 \mathrm{~cm} \times 17 \mathrm{~cm} \times 14.5 \mathrm{~cm}, 2004.900 .052$.

Photo Credit: Marie Astrid González, The Wende Museum of the Cold War.

The Wende Museum's focus on contemporizing Cold War history is perhaps best represented in a signature icon: a slightly larger than life bust of Lenin spray-painted pink and turquoise. [Figure 3] The sculpture's unique Warholian whimsy is indebted to an unknown person who tagged Lenin during one of the pivotal Leipzig demonstrations in 1989 that precipitated the fall of the Berlin Wall. Because such paints originated in West Germany, this iconoclastic 
act represents the fairly misunderstood cross-border exchange that took place in a divided Germany. ${ }^{8}$ Struck by the ambiguous cultural and historical significance of the bust, the museum has adopted the vandalized Lenin as its institutional mascot.

Just as it did before in its smaller office park space, the Wende Museum continues to invite visitors to tour its vault. Indeed, the museum functions as much as a repository of primary source materials for the scholarly expert as it does as an exhibition space invested in educating a general audience on the Cold War's material history. (As a means of opening its materials to a wider public, the museum worked with the German publisher Taschen to produce a hefty book-released in 2014-that contains a small selection of the Wende Museum's East German collection.) The archive of more than 100,000 objects teems with the past: paintings and flags, magazines and street signs, slides and films, fashion and hobby magazines, family photos and art history slides, office chairs and "garden eggs." Busts of Lenin, Marx, Thälmann, and other communist heroes gaze squarely behind earthquake-proof cording. The archive includes a growing number of artworks. Those of East German origin are primarily examples of Auftragskunst (state-contract art), but it also holds a small selection of artist books, self-published samizdat, and photography portfolios include works by Gundula Schulze Eldowy, Ulrich Wüst, and Helga Paris-a few of the handful of photographers whose GDR-era work has been wellreceived in a reunified Germany. In fact, the marginalization of East German culture as politically

${ }^{8}$ For some discussion of this exchange in the art context, see: April Eisman. "East German Art and the Permeability of the Berlin Wall." German Studies Review 38:3 (2015): 597-616. Print. 
suspect has largely devalued its artists, regardless of political affinity. Until recently, the official art of East Germany has disproportionately represented the country's artistic canon.

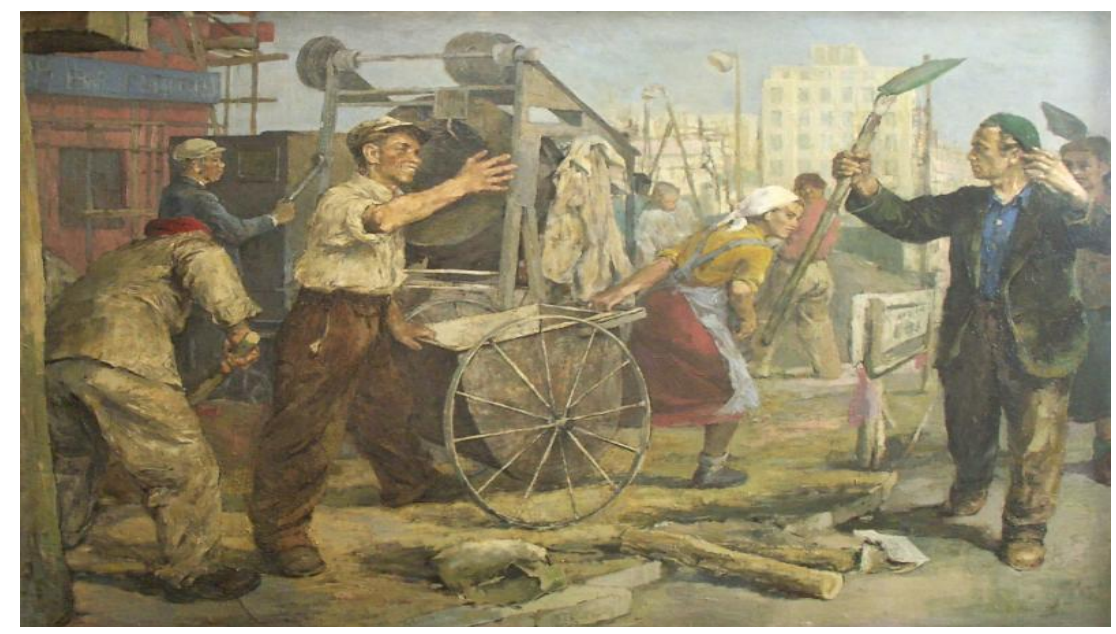

Heinz Drache, Das Volk sagt ' $j a$ ' zum friedlichen Aufbau, 1952, East Germany, oil on canvas, $149 \mathrm{~cm}$ x 212cm, 2007.059.011. Courtesy of the Wende Museum of the Cold War.

Despite its relative exposure, Auftragskunst has nevertheless also been largely misunderstood, colored by simplistic propagandistic interpretation. Consider for example, Jampol's revised interpretation of Heinz Drache's large-format painting Das Volk sagt 'Ja' zum friedlichen Aufbau (The People Say 'Yes' to Peaceful Reconstruction) (1952) (Jampol, "GDR on the Pacific" 259). [Figure 4] By all appearances, the painting exemplifies the hyper-politicized socialist realist aesthetic characteristic of Auftragskunst and "communist" art more generally. Though the painting was indeed state-contracted, it was relegated to a basement 
shortly after a pivotal construction worker's uprising in East Berlin in 1953. Authorities believed that the painting of workers building the city's grand Stalinallee (today's KarlMarx-Allee) would have reminded the country's population of the conditions under protest, as well as aggressive suppression of citizen dissent by Soviet troops. This important detail emphasizes a need for subtle interpretation of official artworks from East Germany.

The Wende Museum invites scholars worldwide and students from local universities to research its holdings. Jampol envisioned this objective after experiencing difficulty accessing such material for his dissertation: "At first, I was interested in pursuing these materials for my own research, then providing them to others for interdisciplinary work, and then, eventually, for other purposes. It all started from there" (cited in Heller). I recently consulted the museum's collection of amateur photography. I reviewed thousands of photographs, many of which had been donated in beautifully organized scrapbooks. Importantly, these collections were made for both public and private audiences. Among my favorites are the official albums of Freie Deutsche Jugend (FDJ, Free German Youth, the GDR's official youth organization) excursions that illustrate both political lessons and leisure. Most of the photos in the Wende Museum's collection are even less politically loaded: average people on vacation, celebrating birthdays and weddings, etc. I found two albums by Heinrich, an amateur photographer and retiree from Dresden. Interspersed among photos of family and friends, he placed ones of house repairs, "old and new clocks," typewriters, and the curious burial of a broken lamp. Are these images of functional living a mockery or a sincere reflection of the GDR's often makeshift consumer economy? Do they demonstrate Heinrich's dissatisfaction 
with a faulty lamp or a leaky faucet? Are they indications of Heinrich's parallel interest in the DIY? The question of how to look at the photographs without anticipating a political message disrupts my ability to draw a conclusion. Some may say that without the oral history that accompanies these photos, I cannot do much more than describe their contents. I do not disagree. Nevertheless, equally quotidian East German artifacts consistently face this kind of political attachment.

Cristina Cuevas-Wolf unites these two genres of scrapbook-the ideological and the personal-under the framework of snapshot or amateur photography. East Germany actively encouraged at home photography, particularly after the introduction of the instant camera to the commercial market in the 1960s. Certainly such handy photography not only enabled personal recording, but also impacted secret police (Stasi) strategies of surveillance. ${ }^{9}$ In any case, the candid look of the snapshot "found its way into the brigade, pioneer, and FDJ scrapbooks and other official photo albums that chronicled, for example, party congresses, urban planning projects and state achievements" (Cuevas-Wolf 37). An analysis of these amateur-made albums-official and unofficial-leads Cuevas-Wolf to conclude "that photography does not show

${ }^{9}$ Cuevas-Wolf actually groups Stasi employees and informants into her description of amateur photographers, writing, "This technology of picture-making becomes an extension of daily life...especially in the hands of serious GDR amateur photographers, such as Manfred Beier (1927-2002), and the East German Ministry for State Security (Stasi) that amassed an extensive photographic archive of its members and activities, in addition to the amateur photographs it gathered from unofficial informants" (36). In a footnote, she continues that "The Stasi even organized internal amateur photography exhibitions to inspire its employees" (36 ff5). 
history but rather it reveals different formal constructs or moments through which we can visualize history" (38). The East German scrapbook is then not just an artifact or document that records a particular moment in history. It is a cultural practice of history making. In short, the impulse to self-record is a cultural phenomenon that crossed public and private realms. Recordings of a party gathering, whose politics clearly motivated image production, are no less authentic than those Heinrich made of himself and his clocks. Both reveal a communicative paradigm centered on photography, specifically the way this medium functioned in the recording of the East German everyday. This method comes into sharper focus when examining photographs that tow the line of affectation and genuine self-expression.
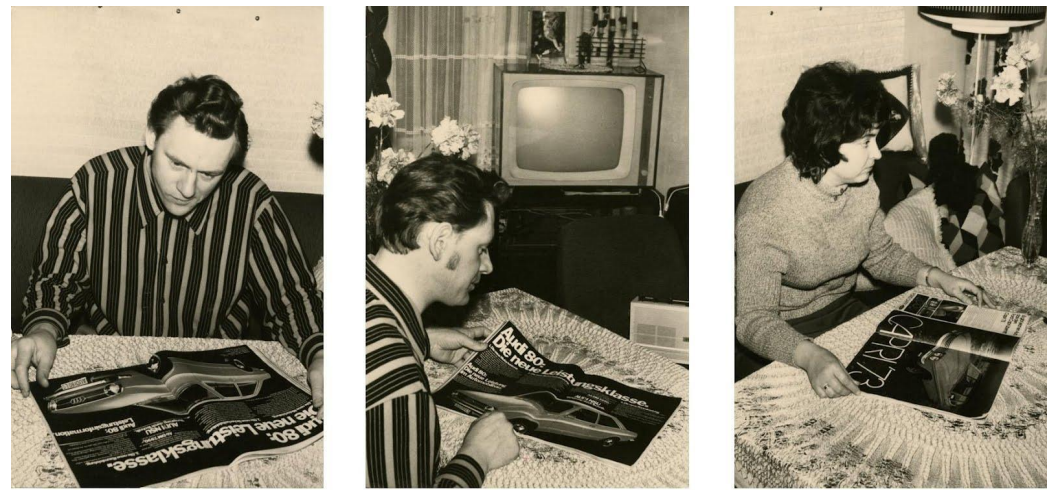

Authors Unknown, Loose vernacular photographs, ca. 1973, Zittau, East Germany, 2005.056.009.

Courtesy of the Wende Museum of the Cold War.

How can I read these photographs without inferring the country's oppressive public politics? Three photographs from 1973 that I found in the collection raise this 
methodological question quite poignantly. [Figure 5] In two images, a man stares lustily at a magazine advertisement for an Audi '80. His hair is coifed in a pompadour and he wears a button-up shirt with a bold striped pattern. Sideburns reach to just below his ear. It is easy to imagine bell bottoms or blue jeans hiding beneath the small table where he is seated. The room is filled with regional textiles-lace on the table, sheer curtains-and signature East German design - a plastic radio on the floor could easily be now a part of the Wende Museum's collection. A candelabra that sits on top of a television set, like the oversized light fixture that hangs in one corner of the room, are standards in mail order catalogues of East German consumer goods. The man's companion-and photographer-appears in picture number three. The two have switched places, though her car companion is now a Ford Capri '73. Her pose is more candid than his. Her fingers graze the car, but her gaze looks off camera, perhaps to something on the television across the room. She has a short modern haircut and wears a tight sweater, in keeping with the time. The man's exaggerated longing for the Audi may, however, be just as genuine as her seeming disinterest. These images raise the issue of East German desire and desire, in general. If I am to believe the narrative of East German history, then I could presume that these young people are lusting after the West. Consumer evidence may support this conclusion: these cars definitely would not have been available in the East. In fact, the presence of these Western magazines itself offers mysterious insight into the cross-cultural exchanges that penetrated the Iron Curtain. However, I can imagine the very same photographs taken across the border in the capitalist West. Were these photos taken in West Germany in 1973, the desire for fast and flashy cars could be read as 
symptomatic of a commercialized Easy Rider youth culture. Does the fact that these photographs were taken in Zittau, East Germany change the desire for a car? Is it fair to politicize the desire because it occurs in East not West Germany?

Close up of back of Figure 5. Authors Unknown, Loose vernacular photographs, ca. 1973, Zittau, East Germany, 2005.056.009. Courtesy of the Wende Museum of the Cold War.

There is another, at first seemingly tangential way of assessing these photographs. Nina Lager Vestberg's account of archival value, specifically how to account for the messaging or meaning making of a historical object, draws attentions to their uses rather than their content. She advises turning a photograph over-particularly in the absence of a clear author or narrative, "downplay[ing] the significance of the image itself, in its capacity as a documentary record of an historical event, by focusing instead on the historicized function of the print as a physical commodity" (Vestberg 51). On the back of the photographs from the Wende Museum is a stamp and an 
illegible scribble in pencil. [Figure 6] The stamp reads "Foto HO-I-Zittau Nr. 11(?) / 28 / 20." "By turning the photograph over," Vestberg writes, "we may find ourselves faced with another type of index, which points to something else...the stamps or scribbles imprinted on its back are indices of something equally intrinsic to its material realization, namely the system of production in which it was generated and disseminated" (53). The stamp informs us that the car-loving man and his indulgent spouse $^{10}$ processed their performances of desire for consumer goods from the West not in the privacy of a home developing lab, but in a public studio-a place where negatives and prints were vulnerable to reproduction by and for state (read: secret police) uses. Here, then the trace of a photograph's use, or its status as a commodity-this is after all its final stage of production-summons relevant questions about the anxiety an average East German had over the threat of punishment for the "anti-socialist" behavior these photos hyperbolically illustrate. Here also is a union of the photograph in and of itself, and the widespread cultural practice of self-staging for the camera. The purpose of these photographs seems to be to record everyday desire, not in its fulfillment, but in its enunciation.

${ }^{10}$ She wears a wedding band on her right hand, which is customary; his ring finger is not visible. 


\section{Eigensinn}

Cultural historian Oana Godeanu-Kenworthy writes that "following the absorption of East Germany into West Germany, as the GDR past has become a signifier without a signified, the same past consequently has become open to invention and to remembering according to the compensatory needs of the present" (169). Because the East has not been allowed to speak for itself, its artifacts cannot self-categorize. The micro-histories present in GDR ephemera have tended to be subcategorized to become representative of either the specter of East German oppression or East German dissidence. Whereas it is absolutely true that the state oppressed, surveilled, and restricted the freedoms of the GDR's population to both general and very specific, often tragic ends, analyzing East Germans and their past with the assumption of victimhood has led to a tendency to infantilize the communist Germany. Such a perspective verifies the West German narrative of German reunification as heroic exploit, establishing a clear moral hierarchy with West as hero and East as either rescued or fascist. This bias has led to a distorted view of the Nischengesellschaft (niche culture), a parallel and networked public that established alternative economies, collectivized to gain access to or protest scarcity, as well as hosted artistic and intellectual events, all as a means to supplement the shortcomings of the culture provided by the state. Considering how the niche culture influenced or even through its defiance forced changes to national character is significant. Josie McLellan's discussion of the role of civil disobedience in establishing legal nudism is, for example, quite telling (McLellan). Similarly, looking at this second sphere through Alf Lüdtke's concept of Eigensinn (a sense of one's self interest) highlights the 
agency citizens enacted as consumers within their private publics (Pence and Betts 5). Because Eigensinn has become a tool to understand the individual's Alltagsgeschichte, it stands to reason that looking at the Alltag ephemera as hosts or sites of Eigensinn may be a useful method to visualize and restage everyday experience. In this sense, the photographs in the Wende Museum collection, as well as the objects within them, bear double-witness. Perhaps Heinrich's photograph of his broken lamp accompanied an official complaint about a lamp of poor quality. ${ }^{11}$ Because such complaints remain in the government record, as do the changes in policy caused by them, including Heinrich's Alltag photographs or the Zittau couple's rendezvous with car advertisements in a historiography of the East German everyday could reasonably contribute to a more dynamic understanding of GDR Eigensinn and consumer behavior.

The inherent everydayness of the Nischengesellschaft clearly destabilizes the villain/victim master narrative that has typified popular conceptions of East Germany. Moreover, investigating the Nischengesellschaft on its own terms reveals an apolitical public. In fact, part of what makes GDR Alltag problematic is that citizens neither largely supported nor resisted their government (Ten Dyke 153). The majority of the East German population "made do" (153) and participated dispassionately within a corrupt system. In his foundational text on East German Alltag, Günther Gaus observes that "niches are not external [to the

${ }^{11}$ See for example Judd Stitziel's chapter about how consumer culture became a conduit between government and Alltag. "Shopping, Sewing, Networking, Complaining. Consumer Culture and the Relationship between State and Society in the GDR." Socialist Modern. Eds. Katherine Pence and Paul Betts. Ann Arbor: University of Michigan Press, 2011. 253-286. Print. 
socialist system], on the contrary they are niches inside GDR socialism...Over the decades more facts, beliefs, and standards of really existing socialism have made themselves at home in private corners that niche dwellers are always themselves aware of" (cited in McLellan 210). That is to say, East Germans both consciously and unconsciously adapted their needs to both accommodate and distress the state system.

Though examples of the hybrid compliant/ resistant East German are vast, personal accounts of the Jugendweihe (the state-sponsored and all but compulsory rite of passage that inaugurated a young person's first adult commitment to the state) are particularly useful in illustrating the ambivalent, even beneficiary, relationship that citizens had to the status quo. On a visit in the early 1990s to a private Alltag museum organized by three Dresden students, anthropologist Elizabeth Ten Dyke recorded one student's account of her Jugendweihe (145). Sabine completed both her Jugendweihe and her church confirmation at the age of 14 . Because it included an avowel of atheism, the Jugendweihe conflicted with Sabine's Christian faith. Nevertheless, she described this conflict of interest as only superficially distressing. At the time, $95 \%$ of East German youth participated in the Jugendweihe (153). Had she opted out, Sabine would have marginalized herself and likely not been admitted to university. As for a growing number of teenagers, for Sabine the Jugendweihe represented a rote performance for the state. As such, it did not conflict with her Christian identity, which mattered more to her personally. This example of Eigensinn undermines the official statistics, which-without the introduction of personal historiesinaccurately characterize GDR youth as overwhelmingly supportive of (or at least submissive to) the state. Ten Dyke describes Sabine's behavior as characteristic of the East 
German experience: "As long as an individual 'played along' or 'participated'...one could achieve those basic things one desired, such as education, while maintaining one's peace and quiet" (155). The historian Mary Fulbrook has of course defined the GDR society as a "participatory dictatorship" - a description that foregrounds "a somewhat oxymoronic" experience (12). The term, she continues, "intend[s] to underline the ways in which the people themselves were at one and the same time both constrained and affected by, and yet also actively and often voluntarily carried, the ever changing social and political system of the GDR" (12). That most East Germans "played along" reveals that for the average East German, identity was positioned, with public and private personae negotiable. Accepting these negotiations is imperative to understanding the East German experience. Focusing on the state as it saw itself and its people strips the agency that Sabine clearly enacted within the system for her personal benefit. To acknowledge this union of compliance, self-assertion, and pragmatism undermines the narrative of omnipresent state power that appears in state documents.

\section{Memory and the Construction of History}

"To claim the right of memory is to call for justice." Pierre Nora, Reasons for the Current Upsurge in Memory

Sabine's choice to include her Jugendweihe in her Alltag museum illustrates well the contradictions that often define subjective experience. This is, no less, a pointed example of how individual memory differs from institutionalized history. Susan Crane names the contradictions inherent to the typical presentation of history in museums and the personal experiences visitors bring to historical institutions 
an "excess of memory." She writes "what I am calling an 'excess' is neither extra nor supplementary to a fictive whole of collective or historical memory; it is what characterizes individual experiences at museums and individual memories of 'the museum' which then shape the public discussion of what museums are and what they could or should be (47). Writing in 1997, Crane notes then recent changes to museum and historical practice, namely a move towards people's histories. Now two decades later, audiences expect discursive and adaptive spaces with relatable displays and themes, and museums have knowingly updated their instructional and pedagogical models. This is not universally true, however. Crane observes that the troubles with working through the Nazi past have influenced the museification of Cold War history. She writes that "the discourse on memory is particularly fraught," evident in, for example, "the slogan for 1990, 'bringing together what belongs together,' [which] belies the vast differences of experience and memory which people of the same generations bring to the new state from east and west" (54). Moving to a then more developed controversy over memory and museums, Crane observes the ways in which newer Holocaust museums had "pitted commemoration against education and interpretation" (59). These museums had begun to allow survivor testimonies and memories to misalign, even contradict, historical narratives. While the stakes of suffering are much lower in the memory of East Germany-which, in spite of its authoritarian policies maintained some important facets of democracy - the value of bearing witness to, rather than assessing or summarizing the GDR experience, is analogous. Here, the Wende Museum's resistance to ideological or politicized narratives, specifically through the primacy of its archive, offer not so much a novel 
presentation of history, but rather one in which a view of impartiality and broad-mindedness accord with the museum practices for which Crane and other experts have long advocated.

Crane's defense of the "excess" of memory-which she also defines as a kind of welcomed, albeit critical "distortion"-reveals the influence of the historian Pierre Nora's theory of lieux de mémoire, sites of memory, which have replaced (or supplanted the necessity for) "real" environments of memory-mileux de mémoire. Memory is portable, globalized even, and does not require a specific place to be authentic. Lieux de mémoire can and often are materially based, that is to say rooted to objects more than sites. They are dynamic, contradictory, and resist the clear narratives that have typified history. Nora offers not just a suggestion, but an assessment of modern uses of history: "We have seen the end of societies that had long assured the transmission and conservation of collectively remembered values, whether through churches or schools, the family or the state; the end too of ideologies that prepared a smooth passage from the past to the future or that had indicated what the future should keep from the past" ("Between Memory and History" 7). We are in a new era, one in which individuals contribute to the telling of their history: "The imperative of our epoch is not only to keep everything, to preserve every indicator of memoryeven when we are not sure which memory is being indicated-but also to produce archives" (14). For Nora, the introduction of a new memory (i.e., history) contributes to greater equality. The indiscriminate production of archives "is the acute effect of new consciousness, the clearest expression of the terrorism of historicized memory" (14).

A kind of "terrorism", or better said hegemony, still persists in German historicizations of the Cold War. 
Jonathan Bach, Cristina Cuevas-Wolf, and Dani Kranz, for example, identify a national mandate to focus on Germany's "macrohistory" in the wake of reunification: "They [museum professionals in Germany] see themselves as helping to forge a postwar narrative of Germany's division and unification" (119). Bach, Cuevas-Wolf, and Kranz continue that although executed with accuracy and accountability, "in keeping with this privileging of macrohistory, it is possible to discern the workings of an official story: the ineluctable failure of socialism together with the inevitable success of democracy and capitalism... [to the effect that] the stories they tell are necessarily smoothed into a larger narrative of German history that depicts reunification as a form of victory" (119120). Museums of East German history-like Leipzig's ZGF-have embraced the condensed and victorious topdown model of historicization that both Nora and Crane advise against. Indeed, in the view of Bach, Cuevas-Wolf, and Kranz they have avoided exploring a "full range of experiences under socialism" for fear of relativizing the repression of the East German regime (121). This reticence relates, of course, to Crane's observations about the historicization of Nazi history. Indeed, although scholars today resist naming East Germany a totalitarian state, that narrative persists in German popular thought. To relativize dictatorship would thus invite the same treatment of the Nazi era. As such, attention paid in the ZGF's exhibits to everyday culture are defined in relation to oppression or citizen rebellion rather than as examples of East German autonomy. One may wonder then how the Kulturbrauerei's museum on the GDR, which offers a more nuanced view of East German Alltag and which is organized and operated by the national House of History $(\mathrm{HoH})$, could exist. Bach, Cuevas-Wolf, and Kranz suggest that the museum, opened 
in 2013, was in fact a concession paid by the $\mathrm{HoH}$ in response to the ascendance of privately funded museums on Germany dedicated to more neutral accounts of the East German everyday (121).

Clearly part of the difficulty with the museification of East Germany relates to location. Because this past is for the most part presented in Germany, museums that focus on East Germany suffer from what I see as Nora's double-bind. Given that it is located in Leipzig - an international cultural and political center of East Germany-the ZGF is in fact both lieux and mileux de mémoire. That is to say, many of the artifacts and stories on display in the museum bear the affirmative weight of original or authentic locationmilieux de mémoire's defining element. It is of course reasonable to believe that location similarly affects independent, that is to say not-state-run, German museums that focus on alternative East German histories. For example, the Dokumentationszentrum Alltagskultur der DDR (Dok-Zentrum, Documentation Center for the Everyday Culture of the GDR) embraces the local origins of its environs and collection. Indeed, given that the DokZentrum acquired many of its objects from local residents (Ludwig cited in Blaylock "Whither Alltag") and that it is located in Eisenhüttenstadt-a surviving example of communist-era urban planning-the museum is understandably unwilling-even unable-to frame its artifacts through the top-down style of narration employed by the ZGF. Political insight or regime critique are not absent here, but are, nevertheless not emphasized to the same degree. Rather, the rhetoric of the Eisenhüttenstadt museum offers a fairly neutralized account of East German culture and people's histories. Exhibitions focus on topics such as plastic design or the Bauhaus, work environments or free-time. Indeed, in its intentional resistance to the 
hegemonic master narrative of East Germany, the DokZentrum self-consciously distinguishes itself from other museums of GDR history (Ludwig cited in Blaylock "Whither Alltag").

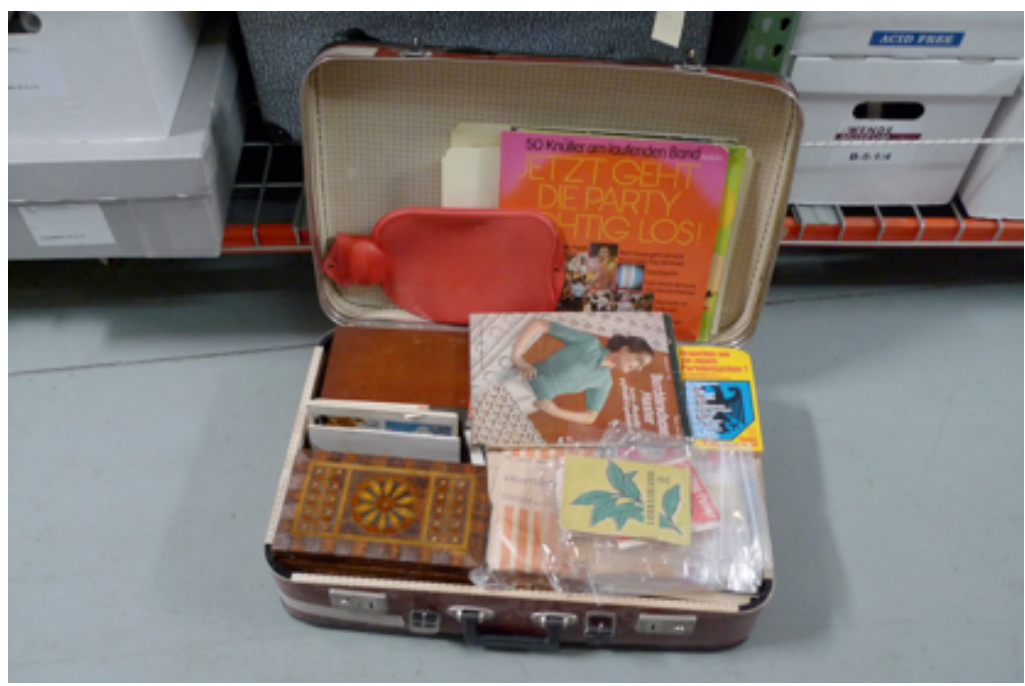

Suitcase filled with everyday items, as received by the museum in early 2000s. Photo Credit: Sara Blaylock, 2012, The Wende Museum of the Cold War.

In contrast, the Wende Museum's great distance from the epicenter of debates over how best to represent Germany's Cold War collective memory enables it to fully embrace Nora's vision of a more open and discursive lieux de mémoire model of history-making. A California location precludes the possibility of mistaking the museum for an original or authentic location. Its resistance to "scripting conclusions" (Jampol, "GDR on the Pacific" 262) is, however, optional. That is to say, the Wende Museum's choice to offer 
historical evidence rather than to tell history enables it to become an alternative space for history making rather than history telling. After Andreas Huyssen, this is, thus, a repository for "present pasts" that is oriented toward a future as yet undecided (21). The Wende Museum's to-bedetermined focus is not end obsessed, but rather nonpurposeful in the sense that the museum hedges conclusion and, therefore avoids future contradiction. Indeed, because it does not mediate its visitors' experiences through a unilateral historicization, the museum allows memories and associations to surface freeform and unresolved. This is especially significant for visitors who lived in the communist Germany and who have few opportunities to engage with this past outside the familiar dichotomies of state oppression or citizen resistance. Donations from East Germans evince their desire to preserve personal history, while also demonstrating a persistent need for historicization that is-to think with Crane-both excessive and willingly distorted. A donation to the Wende Museum offers greater assurance that the East German past will neither end up in the trash nor in an overtly politicized museum display. A particular example comes to mind. [Figure 7] Several years ago, a suitcase filled with books, records, magazines, and political texts arrived from Germany. This donation signifies the refined purpose of reclaiming the East German past through Alltag. Everyone's memories get lost, but in this case, the donor wants to contribute to the archiving of their past. Such work is achieved in no small part through the presence of objects that defy an easy categorization or narrative. Furnished with personal photographs, records, magazines, boxes of knick knacks, official brochures, as well as a hot water bottle, the suitcase contains the idiosyncrasies of a person's life. Included are those unpredictable fragments of an 
individual's life that may stir the memories of strangers. There is a kind of democratization at work here-or at least the representation of the ways that an object can be one and many things to many people.

\section{Ostalgie and Self-Affirmation through Objects}

According to Nora, memory "takes root in the concrete, in spaces, gestures, images, and objects" ("Between Memory and History" 8). That is to say, culture manifests itself in objects, and as such it can be passed through time. Similarly, the anthropologists Mihaly Czikszentmihalyi and Eugene Rochberg-Halton observe that this kind of communication enables tradition, and theorize that these mediated communications between past and present shape collective memory. Objects are role models: "Even purely functional things serve to socialize a person to a certain habit or way of life and are representative signs of that way of life" (21). For example, a house is a traditional type of dwelling whose tradition is relative to its position, not to any universal definition of what a dwelling should be. Thus, by looking at the things that surround a person, one gains insight into not only the individual, but also the shared experience that shaped that individual's life and worldview. Similarly, individuals manifest their memories in collections of personal objects, what art historian Jennifer González calls "autotopographies." She explains that through these collections "one forms modes of selfrepresentation...not only to reflect memories and desires but also to protect a threatened identity" (140). Autotopographies-especially of the displaced or marginalized-may be composed of transitional objects, which aid the psychosocial transformations a people must 
undergo when transplanted from a familiar cultural context to a new and often hostile space (140).

Following reunification, East Germans lamented that they had "emigrated without leaving home" (Berdahl, "(N)ostalgie for the Present" 202). The East German transitional object may help ease the material and cultural unease caused by the literal loss of a country by marking the new reality with pieces of the old. Nevertheless, Alltag ephemera have been disregarded as ostalgic, a cultural phenomenon which describes nostalgia for East (Ost) Germany. Since unification, Ostalgie has been especially evident in the market for East German products, a fetishization popularized and made internationally recognizable by the 2003 film Good Bye Lenin!, as well as by the success of Berlin's hands-on DDR Museum. Some scholars argue that what is today a kitschy commodification of East Germany began as an effort to ease its former citizens into a reunified Germany. Daphne Berdahl, for example, suggests that this inclusion, rather than assisting cultural transition, focused entirely on adjusting East Germans from communist to capitalist consumers and thus "perpetuated a narrative of 'democratization' and national legitimacy in which access to consumer goods and consumer choice [was] defined as a fundamental right and a democratic expression of individualism" ("Re-Presenting the Socialist Modern" 360361). In light of the failure to include East German culture outside the gift shop, this argument is especially convincing.

Alternatively, Ostalgie may be conceived as a Western invention - an imaginary that has helped to maintain the Cold War narrative of victory over communism, which also 
preserves a fantasy of an Eastern utopian alternative. ${ }^{12}$ Anthropologist Dominic Boyer considers Ostalgie to be a nostalgic phenomenon that resonates more with a West than an East German identification. In his view, in order to stabilize the West's post-Nazi identification, East Germans must remain West German's muted Other:

The very powerful and diverse Ostalgie industry in unified Germany reflects the desire of its West German owners and operators to achieve an unburdened future via the repetitive signaling of the past-obsession of East Germans. But this incessant signaling is itself symptomatic of West Germany's own past-orientation. In the end, the therapy of East/West distinction cannot really resolve or dissolve what Freud might have termed the pathogenic nucleus of the Holocaust in all postwar German memory. Nevertheless such therapy exerts tremendous effects upon the lives and self-knowledge of eastern German citizens. ("Ostalgie and the Politics of the Future in Eastern Germany" 363)

Boyer's analysis suggests a deeper and more problematic subtext to the controversy over East German memory. This is not "simply" a question of retelling the Cold War. Rather, revising East German history potentially derails the long sought after Selbstwertgefühl (self-respect/esteem) of the post-Nazi (West) German. Such a derailment will arguably serve to further the restoration of German-German identification, healing the political divide that severed ties between post-war Germans along ideological lines, ones which reflect and shape popular belief, but which

12 See for example Boyer, Berdahl, and Godeanu-Kenworthy cited in this document as well as the "Former West" project: http: / / www.formerwest.org. 
nevertheless muddy when attentions are paid to everyday details.

The interests and potential influences of a renegotiation of East German history extend beyond the experiences of East or West Germans, themselves. As Mary Hampton and Douglas Peifer have argued, the inclusion or exclusion of certain facets of German history can profoundly shape foreign and domestic policy. As their example related to an embrace of Germany's Prussian past demonstrates, the welcoming of this Eastern-rather than Westernformulation of German identity in fact helped the public to accept Germany's advocacy for the admission of Poland and the Czech Republic into NATO and the European Union (382). One could imagine, then a different kind of German identity emerging out of a more generous, or at least more nuanced, appraisal of Germany's Cold War history that takes into account East German experience. With the rise of nationalism and anti-immigration sentiment largely concentrated in the "new" German states located in the former GDR, this work is arguably more pressing than ever.

\section{Acknowledgements}

Thank you to Christine Rank and the Wende Museum of the Cold War for support in the archive, and for the image permissions.

An earlier version of this text appeared in the graduatestudent journal Verges: Germanic and Slavic Studies in Review in 2013 


\section{Works Cited}

Bach, Jonathan, Cristina Cuevas-Wolf and Dani Kranz. "Objects." Ruptures in the Everyday. Views of Modern Germany from the Ground. Eds. Andrew Stuart Bergerson and Leonard Schmieding. New York and Oxford: Berghahn Books, 2017, 113-142. Print.

Berdahl, Daphne. " '(N)ostalgie' for the Present: Memory, Longing, and East German Things." Ethnos: Journal of Anthropology 64:2 (1999): 192-211. Print.

—, "Re-Presenting the Socialist Modern: Museums and Memory in the Former GDR." Socialist Modern. Eds. Katherine Pence and Paul Betts. Ann Arbor: University of Michigan Press, 2011. 345-366. Print.

Biehl, Jody K. "A Cold War Museum in Sunny Climes. East Germany Goes Hollywood." Spiegel International. Spiegel International, 22 April 2005. Web. 2 September 2019.

Blaylock, Sara. Infiltration and Excess: Experimental Art as Public Life in the Late East Germany (Manuscript in Progress, anticipated 2022 with The MIT Press).

— . "Whither Alltag? How the Wende Museum revises East German history (and why it matters," Verges: Germanic \& Slavic Studies in Review 2:2 (2013). PDF.

Boyer, Dominic. "From Algos to Autonomos, Nostalgic Eastern Europe as Postimperial Mania." Post-Communist Nostalgia. Ed. Maria Todorova and Zsuzsa Gille. New York: Berghahn Books, 2010. 17-28. Print.

- "Ostalgie and the Politics of the Future in Eastern Germany." Public Culture 18:2 (2006): 361-381. Print.

Crane, Susan A. "Memory, Distortion, and History in the Museum." History and Theory 36:4, Theme Issue 36: Producing the Past: Making Histories Inside and Outside the Academy (December 1997): 44-63. Print. 
Csikszentmihalyi, Mihaly, and Eugene Rochberg-Halton. The Meaning of Things. Domestic Symbols and the Self. Cambridge, UK: Cambridge University Press, 1981. Print. Cuevas-Wolf, Cristina. "Making the Past Present: GDR Photo Albums and Amateur Photographs." Visual Resources 30:1 (2014): 33-56. Print.

Daley, Jason. "Berlin's Famous East Side Gallery Protected from Development." Smithsonianmag.com. Smithsonian Magazine, 27 November 2018. Web. 1 September 2019. DDR-Museum Tutow. Web. 16 January 2020.

"Developer Resumes Removal of Berlin Wall Section for Luxury Housing." Spiegel International. Spiegel International, 27 March 2013. Web. 2 September 2019.

Dueck, Cheryl. "The Humanization of the Stasi in 'Das Leben der Anderen." German Studies Review 31:3 (October 2008): 599-609. Print.

Eisman, April. "East German Art and the Permeability of the Berlin Wall." German Studies Review 38:3 (2015): 597-616. Print.

Former West. Web. 16 January 2020.

Fulbrook, Mary. The People's State: East German Society from Hitler to Honecker. New Haven: Yale University Press, 2005. Print.

Giannachi, Gabriella. Archive Everything. Mapping the Everyday. Cambridge, Mass. \& London: The MIT Press, 2016. Print.

Godeanu-Kenworthy, Oana. "Deconstruction Ostalgia: The National Past Between Commodity and Simulacrum in Wolfgang Becker's “Good Bye Lenin" (2003)." Journal of European Studies, 41:2 (2011): 161-177. Print.

González, Jennifer A. "Autotopographies." Prosthetic Territories: Politics \& Hypertechnologies, Eds. Gabriel Brahm and Mark Driscoll. Boulder: Westview Press, 1995. 133150. Print. 
Good Bye, Lenin! Dir. Wolfgang Becker. Perf. Daniel Brühl, Katrin Saß, Chulpan Khamatova, Maria Simon, Alexander Beyer. Screenplay by Wolfgang Becker and Bernd Lichtenberg. X-Filme Creative Pool, 2003. FOX, 2004. DVD.

Hampton, Mary N., and Douglas C. Peifer. "Reordering German Identity: Memory Sites and Foreign Policy." German Studies Review 30:2 (May 2007): 371-390. Print.

Heller, Steven. “Cold War Relics: The Wende Museum Saves Communist Design." The Atlantic. The Atlantic, 11 August 2011. Web. 2 September 2019.

Howes, Seth. "'Killersatellit' and Randerscheinung: Punk and the Prenzlauer Berg."

German Studies Review 36:3 (October 2013): 579-601

- Pessimism and the Politics of the Future in East German Punk." The Journal of Popular Culture 49:1 (February 2016): 77-96.

Huyssen, Andreas. "Present Pasts: Media, Politics, Amnesia." Public Culture 12:1 (Winter 2000): 21-38. Print. Jack, Malcolm. "East Germans Were Welcomed to the West With Free Money. Here's What They Bought After the Berlin Wall Fell." Time.com. Time Magazine, October 31, 2019. Web. January 16, 2020.

Jampol, Justinian. " 'GDR on the Pacific': (Re)Presenting East Germany in Los Angeles.” German Monitor 74 (2011): 251265. Print.

—. "Beyond the Wall." Beyond the Wall. Art and Artifacts from the GDR / Jenseits der Mauer. Kunst und Alltagsgegenstände aus der DDR. Eds. Justinian Jampol, Benedikt Taschen and Ina Pfitzner. Cologne: Taschen, 2014. 11-17. Print.

Kelly, Elaine and Amy Wlordarski, "Introduction." German Monitor 74 (2011): 1-18. Print. 
McLellan, Josie. Love in the Time of Communism. Intimacy and Sexuality in the GDR. Cambridge, UK: Cambridge University Press, 2011. Print.

Museum in der Kulturbrauerei. "Collections. Collection Concept." Stiftung Haus der Geschichte der Bundesrepublik Deutschland. Stiftung Haus der Geschichte der Bundesrepublik Deutschland, n.d. Web. 30 August 2019.

Nora, Pierre. "Between Memory and History: Les Lieux de Mémoire." Representations 26, Special Issue: Memory and Counter-Memory (Spring 1989): 7-24. Print.

—. "From Reasons for the Current Upsurge in Memory." The Collective Memory Reader. Eds. Jeffrey K. Olick, Vered Vinitzky-Seroussi, and Daniel Levy. New York: Oxford University Press, 2011. 437-41. Print.

Pence, Katherine, and Paul Betts. "Introduction." Socialist Modern. Eds. Katherine Pence and Paul Betts. Ann Arbor: University of Michigan Press, 2011. 1-34. Print.

Ten Dyke, Elizabeth A. "Memory, History, and Remembrance Work in Dresden." Altering States. Ethnographies of Transition in Eastern Europe and the Former Soviet Union. Ed. Daphne Berdahl, Matti Bunzl, and Martha Lampland. Ann Arbor: University of Michigan Press, 2000. 139-157. Print.

The Lives of Others (Das Leben der Anderen). Dir. Florian Henckel von Donnersmarck. Perf. Ulrich Mühe, Martina Gedeck, Sebastian Koch, Ulrich Tukur. Screenplay by Florian Henckel von Donnersmarck. Wiedemann \& Berg, Bayerischer Rundfunk Arte and Creado Film, 2006. Sony Pictures Home Entertainment, 2007.

"The Lives of Others - Sound, Set and Colour," Scholarship @ cc. Cromwell College, 18 August 2009. Web. 2 September 2019. 
Vestberg, Nina Lager. "Archival Value. On Photography, Materiality and Indexicality." Photographies 1:1 (March 2008): 49-65. Print.

Wende Museum. "About Us." The Wende Museum. The Wende Museum, n.d. Web. 2 September 2019.

—. "The Wall Project." The Wende Museum. The Wende Museum, n.d. Web. 2 September 2019.

Wiener, Jon. How We Forgot the Cold War: A Historical Journey Across America. Berkeley: University of California Press, 2012. Print. 